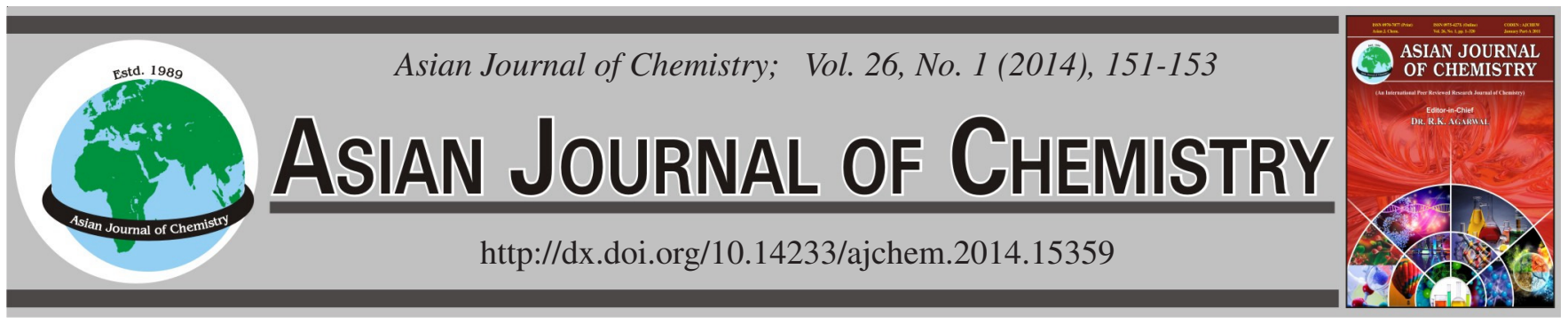

\title{
Synthesis and Crystal Structure of New Trinuclear Nickel(II) Complex $\left\{\left[(\mathrm{NiL})_{2}(\mathrm{OAc})_{2} \mathrm{Ni}\right] \cdot n-\mathrm{BuOH} \cdot \mathrm{CHCl}_{3}\right\}_{2} \cdot n-\mathrm{BuOH}$
}

\author{
Yin-Xia Sun ${ }^{*}$, Rui-E Lu, Yu-Jie Zhang, Wei-Sheng Meng and Xin-Ran Li
}

School of Chemical and Biological Engineering, Lanzhou Jiaotong University, Lanzhou 730070, P.R. China

*Corresponding author: E-mail: sun_yinxia@163.com

\begin{abstract}
A new trinuclear nickel(II) complex with a Salen-type bisoxime chelating ligand $\left(\mathrm{H}_{2} \mathrm{~L}\right),\left\{\left[(\mathrm{NiL})_{2}(\mathrm{OAc})_{2} \mathrm{Ni}\right] \cdot n-\mathrm{BuOH} \cdot \mathrm{CHCl}\right\}_{2} \cdot n$ - $\mathrm{BuOH}$, has been synthesized and characterized. The X-ray crystal structure of the $\mathrm{Ni}$ (II) complex reveals that the unit cell contains two crystallographically independent but chemical identical trinuclear Ni(II) complexes, molecules A and B. Interestingly, the complex possessing different conformational metal centers: penta- and hexa-coordinated geometry. The coordination geometry around the terminal Ni2 and $\mathrm{Ni}^{\# 1}$ atom in molecule $\mathrm{A}\left(\mathrm{Ni} 4\right.$ and $\mathrm{Ni}^{\#}$ in molecule $\mathrm{B}$ ) approaches a distorted square pyramid. The coordination sphere of the central Ni1 atom in molecule $\mathrm{A}$ (Ni3 in molecule $\mathrm{B}$ ) constitutes a slightly distorted octahedral geometry.
\end{abstract}

Keywords: Ni(II) complex, Bisoxime ligand, Synthesis, Crystal structure.

\section{INTRODUCTION}

Salen-type bisoxime ligands and their complexes have attracted much attention in recent years for their novel structures and spectral characteristics ${ }^{1,2}$, especially for their excellent photoluminescence ${ }^{3}$ and interesting magnetic ${ }^{4}$ properties. To the best of our knowledge, in many syntheses of nickel complexes $^{5-7}$, tri-nickel complexes have been determined and the coordination number of nickel(II) atoms is generally six and the coordination geometry around the nickel(II) atoms is octahedron. Herein, a trinuclear Ni(II) complex, namely $\left\{\left[(\mathrm{NiL})_{2}(\mathrm{OAc})_{2} \mathrm{Ni}\right] \cdot n-\mathrm{BuOH} \cdot \mathrm{CHCl}_{3}\right\}_{2} \cdot n-\mathrm{BuOH}$, was synthesized and characterized. X-Ray crystallographic analysis reveals that the structure of the $\mathrm{Ni}$ (II) complex is pseudo-isostructural, in that they are both trinuclear, with two acetate ions coordinated to three $\mathrm{Ni}$ (II) atoms through $\mathrm{Ni}-\mathrm{O}-\mathrm{C}-\mathrm{O}-\mathrm{Ni}$ bridges and four $\mu$-phenoxo oxygen atoms from two [NiL] units also coordinated to $\mathrm{Ni}(\mathrm{II})$ atoms.

\section{EXPERIMENTAL}

4-Methoxy-2-hydroxybenzaldehyde ( $\geq 98 \%$ ) and 1,2dibromoethane were purchased from Alfa Aesar and used without further purification. 1,2-Bis(aminooxy)ethane was synthesized according to an analogous method reported earlier ${ }^{3}$. The other reagents and solvents were analytical grade reagents from Tianjin Chemical Reagent Factory and were used without further purification. Elemental analysis for $\mathrm{Ni}$ was detected by an IRIS ER/S.WP-1 ICP atomic emission spectrometer. C,
$\mathrm{H}$ and $\mathrm{N}$ analyses were carried out with a $\mathrm{GmbH}$ VariuoEL V3.00 automatic elemental analyzer.

General procedure: The ligand $\mathrm{H}_{2} \mathrm{~L}$ was synthesized with a slightly modified method reported literature ${ }^{8}$. Reaction of 1,2-bis(aminooxy)ethane (133.7 $\mathrm{mg}, 1.45 \mathrm{mmol}$ ) with 2 equivalents of 4-methoxysalicylaldehyde $(456 \mathrm{mg}, 3 \mathrm{mmol})$ in ethanol $(10 \mathrm{~mL})$ at $55^{\circ} \mathrm{C}$ for $6 \mathrm{~h}$. After cooling to room temperature, the resulting solid was filtered and washed successively with ethanol and ethanol/hexane (1:4). The product was dried in vacuo and obtained the colourless microcrystal. Yield: $78.9 \%$. m.p. $97-98{ }^{\circ} \mathrm{C} .{ }^{1} \mathrm{H}$ NMR (400 MHz, $\left.\mathrm{CDCl}_{3}\right), \delta$ $3.79(\mathrm{~s}, 6 \mathrm{H}), 4.41(\mathrm{~s}, 4 \mathrm{H}), 6.46(\mathrm{~d}, J=2.8 \mathrm{~Hz}, 2 \mathrm{H}), 6.47$ (s, 2H), 7.04 (d, $J=2.8 \mathrm{~Hz} 2 \mathrm{H}), 8.17$ (s, 2H), 9.94 (s, 2H). Anal. calcd. (\%) for $\mathrm{C}_{18} \mathrm{H}_{20} \mathrm{~N}_{2} \mathrm{O}_{6}\left(\mathrm{H}_{2} \mathrm{~L}\right)$ : C, 59.99; H, 5.59; N, 7.77. Found (\%): C, 59.96; H, 5.85; N, 7.65.

The $\mathrm{Ni}(\mathrm{II})$ complex was synthesized as follows: A solution of $\mathrm{Ni}(\mathrm{OAc})_{2} \cdot 4 \mathrm{H}_{2} \mathrm{O}$ (4.2 mg, $\left.0.015 \mathrm{mmol}\right)$ in $n$-butanol $(3 \mathrm{~mL})$ was added dropwise to a solution of $\mathrm{H}_{2} \mathrm{~L}(6.2 \mathrm{mg}, 0.016 \mathrm{mmol})$ in chloroform $(3 \mathrm{~mL})$ at room temperature. Vapour phase diffusion of $n$-hexane into the solution afforded green blocklike crystals of the $\mathrm{Ni}(\mathrm{II})$ complex. Anal. calcd. (\%) for $\mathrm{C}_{94} \mathrm{H}_{116} \mathrm{~N}_{8} \mathrm{O}_{35} \mathrm{Cl}_{6} \mathrm{Ni}_{6}$ : C, 45.47; H, 4.71; N, 4.51; Ni, 14.18. Found (\%): C, 46.18; H, 4.85; N, 4.49; Ni, 14.05.

X-Ray structure determination: The single crystal of the $\mathrm{Ni}$ (II) complex with approximate dimensions of $0.47 \mathrm{~mm}$ $\times 0.45 \mathrm{~mm} \times 0.42 \mathrm{~mm}$ was placed on a Bruker Smart 1000 diffractmeter equipped with Apex CCD area detector. The diffraction data were collected using a graphite monochromated 
$\operatorname{MoK}_{\alpha}$ radition $(\lambda=0.71073 \AA$ ) at $298(2) \mathrm{K}$. The structure was solved by using the program SHELXS-97 ${ }^{9}$ and Fourier difference techniques and refined by full-matrix least-squares method on $\mathrm{F}^{2}$ using SHELXL- $97^{10}$. Details of the data collection and refinements of the Ni(II) complex are given in Table- 1 . The non-hydrogen atoms were refined anisotropically. Hydrogen atoms were added theoretically. CCDC No.: 909427.

\section{RESULTS AND DISCUSSION}

X-Ray crystallographic analysis of the Ni(II) complex reveals a symmetric trinuclear structure. It crystallizes in the triclinic system, space group P-1 and the unit cell contains two crystallographically independent but chemical identical trinuclear complexs, molecules A and B. Both molecules A and $\mathrm{B}$ consist of three nickel(II) atoms, two $\mathrm{L}^{2-}$ units, two acetate ions, one crystallizing chloroform and one and a half crystallizing $n$-butanol molecules. The molecular structure of the Ni(II) complex is shown in Fig. 1. Selected bond distances and angles are listed in Table-2. In molecule A, the terminal $\mathrm{Ni}(\mathrm{II})(\mathrm{Ni} 2)$ atom is five-coordinated by two nitrogen ( N1 and N2) atoms and two oxygen (O3 and O5) atoms in the $\mathrm{N}_{2} \mathrm{O}_{2}$ moieties of the ligand and one oxygen $(\mathrm{O} 7)$ atom from the bridging acetate anion. Consequently, around $\mathrm{Ni} 2$ atom is slightly distorted square pyramid geometry. In addition, the central nickel (Ni1) coordination sphere is completed by four $\mu$-phenoxo oxygen $\left(\mathrm{O} 3, \mathrm{O} 5, \mathrm{O}^{\# 1}\right.$ and $\left.\mathrm{O} 5^{\# 1}\right)$ atoms from two [NiL] chelates and both of oxygen $\left(\mathrm{O} 8\right.$ and $\left.\mathrm{O}^{\# 1}\right)$ atoms from two acetate anions which adopts a familiar $\mu \mathrm{O}-\mathrm{C}-\mathrm{O}$ fashion ${ }^{11}$

\begin{tabular}{cc}
\hline & TABLE-1 \\
CRYSTAL DATA AND REFINEMENT \\
PARAMETERS FOR THE Ni(II) COMPLEX \\
\hline Empirical formula & $\mathrm{C}_{94} \mathrm{H}_{116} \mathrm{~N}_{8} \mathrm{O}_{35} \mathrm{Cl}_{6} \mathrm{Ni}_{6}$ \\
Formula weight & 2482.91 \\
Temperature & $298(2) \mathrm{K}$ \\
Wavelength & $0.71073 \AA$ \\
Crystal system & Triclinic \\
Space group & $\mathrm{P}-1$ \\
Cell dimensions & $\mathrm{a}=11.3988(11) \AA, \mathrm{b}=13.4488(13)$ \\
& $\AA, \mathrm{c}=18.5332(18) \AA, \alpha=$ \\
Volume & $93.8170(10)^{\circ}, \beta=96.3280(10)^{\circ}, \gamma=$ \\
$\mathrm{Z}$ & $100.039(2)^{\circ}$ \\
Density (calculated) & $2769.9(5) \AA^{3}$ \\
Absorption coefficient & 1 \\
$\mathrm{~F}_{(000)}$ & $1.488 \mathrm{mg} / \mathrm{m}^{3}$ \\
Index ranges & $1.225 \mathrm{~mm}^{-1}$ \\
Reflections collected & 1286 \\
Independent reflections & $-12 \leq \mathrm{h} \leq 13,-15 \leq \mathrm{k} \leq 15,-22 \leq 1 \leq 20$ \\
Data/restraints/parameters & 14259 \\
Goodness of fit indicator & $9533\left[\mathrm{R}_{\text {int }}=0.0291\right]$ \\
Final R indices [I $>3 \sigma(\mathrm{I})]$ & $9533 / 0 / 781$ \\
$\mathrm{R}$ indices (all data) & 1.045 \\
Largest diff. peak and hole & $\mathrm{R}_{1}=0.0587, \mathrm{wR}_{2}=0.1016$ \\
\hline & $\mathrm{R}_{1}=0.0815, \mathrm{wR}_{2}=0.1208$ \\
\hline & 0.489 and $-0.440 \mathrm{e} \AA^{-3}$ \\
\hline
\end{tabular}

and constitute slightly distorted octahedral geometry. Compared with molecule A, molecule B is similar in the structural features but distinct in some bond distances and angles. Furthermore, the trinuclear structure is stabilized by two $\mu$-acetato ligands, which neutralize the whole charge of the $\mathrm{Ni}$ (II) complex.

TABLE-2

SELECTED BOND LENGTHS $(\AA)$ AND ANGLES $\left(^{\circ}\right)$ FOR THE Ni(II) COMPLEX

\begin{tabular}{|c|c|c|c|c|c|}
\hline Atom & Distance & Atom & Distance & Atom & Distance \\
\hline Ni1-O8 & $2.032(7)$ & $\mathrm{Ni2-O7}$ & $2.015(8)$ & $\mathrm{Ni3}-\mathrm{O} 12^{\# 2}$ & $2.076(1)$ \\
\hline $\mathrm{Ni1}-\mathrm{O}^{\# 1}$ & $2.032(7)$ & Ni2-N1 & $2.035(9)$ & $\mathrm{Ni4}-\mathrm{O} 14$ & $1.970(1)$ \\
\hline Ni1-O3 & $2.094(6)$ & $\mathrm{Ni2}-\mathrm{N} 2$ & $2.035(1)$ & $\mathrm{Ni4}-\mathrm{O} 12$ & $1.983(1)$ \\
\hline $\mathrm{Ni1-O3} 3^{\# 1}$ & $2.094(6)$ & $\mathrm{Ni3}-\mathrm{O} 16^{\# 2}$ & $2.015(1)$ & Ni4-N4 & $2.017(1)$ \\
\hline $\mathrm{Ni1}-\mathrm{O}^{\# 1}$ & $2.116(7)$ & $\mathrm{Ni3-O16}$ & $2.015(1)$ & $\mathrm{Ni4}-\mathrm{O} 17$ & $2.023(1)$ \\
\hline Ni1-O5 & $2.116(7)$ & $\mathrm{Ni3}-\mathrm{O} 14^{\# 2}$ & $2.068(1)$ & $\mathrm{Ni4}-\mathrm{N} 3$ & $2.047(1)$ \\
\hline $\mathrm{Ni} 2-\mathrm{O} 5$ & $2.003(7)$ & $\mathrm{Ni3-O14}$ & $2.068(1)$ & $\mathrm{Ni3}-\mathrm{O} 12$ & $2.076(1)$ \\
\hline $\mathrm{Ni2}-\mathrm{O} 3$ & $2.012(7)$ & - & - & - & - \\
\hline Atom & Angle & Atom & Angle & Atom & Angle \\
\hline O8-Ni1-O8 & $180.0(4)$ & O5-Ni2-O3 & $83.2(3)$ & O16 ${ }^{\# 2}-\mathrm{Ni3}-\mathrm{O} 16$ & 180.00 \\
\hline O8-Ni1-O3 & $89.5(3)$ & O5-Ni2-O7 & $94.7(3)$ & $\mathrm{O}^{1} 6^{\# 2}-\mathrm{Ni3}-\mathrm{O} 14^{\# 2}$ & $89.6(5)$ \\
\hline $\mathrm{O} 8^{\# 1}-\mathrm{Ni1}-\mathrm{O} 3$ & $90.5(3)$ & O3-Ni2-O7 & $91.9(3)$ & O16-Ni3-O14 & $90.4(5)$ \\
\hline O8-Ni1-O3 ${ }^{\# 1}$ & $90.5(3)$ & O5-Ni2-N1 & $163.9(4)$ & $\mathrm{O} 16^{\# 2}-\mathrm{Ni3}-\mathrm{O} 14$ & $90.4(5)$ \\
\hline $\mathrm{O}^{\# 1}-\mathrm{Ni} 1-\mathrm{O} 3^{\# 1}$ & $89.5(3)$ & O3-Ni2-N1 & $89.3(3)$ & O16-Ni3-O14 & $89.6(5)$ \\
\hline O8-Ni1-O5 ${ }^{\# 1}$ & $91.1(3)$ & O5-Ni2-N2 & $88.5(3)$ & $\mathrm{O} 16^{\# 2}-\mathrm{Ni3}-\mathrm{O} 12$ & $90.9(4)$ \\
\hline $\mathrm{O} 8^{\# 1}-\mathrm{Ni} 1-\mathrm{O}^{\# 1}$ & $88.9(3)$ & $\mathrm{O} 3-\mathrm{Ni} 2-\mathrm{N} 2$ & $169.5(4)$ & O16-Ni3-O12 & $89.1(4)$ \\
\hline O3-Ni1-O5 ${ }^{\# 1}$ & $101.5(3)$ & O7-Ni2-N2 & $95.2(4)$ & $\mathrm{O} 14^{\# 2}-\mathrm{Ni3}-\mathrm{O} 12$ & $102.5(5)$ \\
\hline $\mathrm{O} 3^{\# 1}-\mathrm{Ni} 1-\mathrm{O}^{\# 1}$ & $78.5(3)$ & $\mathrm{N} 1-\mathrm{Ni2}-\mathrm{N} 2$ & $97.1(4)$ & O14-Ni3-O12 & $77.5(5)$ \\
\hline O8-Ni1-O5 & $88.9(3)$ & O14-Ni4-O12 & $82.0(5)$ & $\mathrm{O} 16^{\# 2}-\mathrm{Ni} 3-\mathrm{O} 12^{\# 2}$ & $89.1(4)$ \\
\hline $\mathrm{O}^{\# 1}-\mathrm{Ni1}-\mathrm{O} 5$ & $91.1(3)$ & O14-Ni4-N4 & $89.4(6)$ & O16-Ni3-O12 & $90.9(4)$ \\
\hline O3-Ni1-O5 & $78.5(3)$ & O12-Ni4-N4 & $164.3(6)$ & $\mathrm{O} 14^{\# 2}-\mathrm{Ni3}-\mathrm{O} 12^{\# 2}$ & $77.5(5)$ \\
\hline $\mathrm{O}^{\# 1}-\mathrm{Ni1}-\mathrm{O} 5$ & $101.5(3)$ & O14-Ni4-O17 & $91.6(5)$ & O14-Ni3-O12 $2^{\# 2}$ & $102.5(5)$ \\
\hline $\mathrm{O}^{\# 1}-\mathrm{Ni1}-\mathrm{O} 5$ & $180.0(2)$ & O12-Ni4-O17 & $93.9(5)$ & O12-Ni3-O12 & 180.00 \\
\hline N4-Ni4-O17 & $99.4(6)$ & N4-Ni4-N3 & $98.4(6)$ & O12-Ni4-O18 & $78.4(8)$ \\
\hline O14-Ni4-N3 & $169.2(5)$ & O17-Ni4-N3 & $94.6(6)$ & N4-Ni4-O18 & $88.2(8)$ \\
\hline O12-Ni4-N3 & $88.7(5)$ & O14-Ni4-O18 & $87.6(7)$ & O17-Ni4-O18 & $172.3(7)$ \\
\hline N3-Ni4-O18 & $85.1(7)$ & Ni2-O3-Ni1 & $95.8(3)$ & Ni2-O5-Ni1 & $95.4(3)$ \\
\hline Ni4-O12-Ni3 & $96.6(5)$ & Ni4-O14-Ni3 & $97.3(5)$ & - & - \\
\hline
\end{tabular}

Symmetry transformations used to generate equivalent atoms: ${ }^{\# 1}-\mathrm{x}+1,-\mathrm{y}+1,-\mathrm{z}+1 ;{ }^{\# 2}-\mathrm{x}+2,-\mathrm{y}+2,-\mathrm{z}$. 


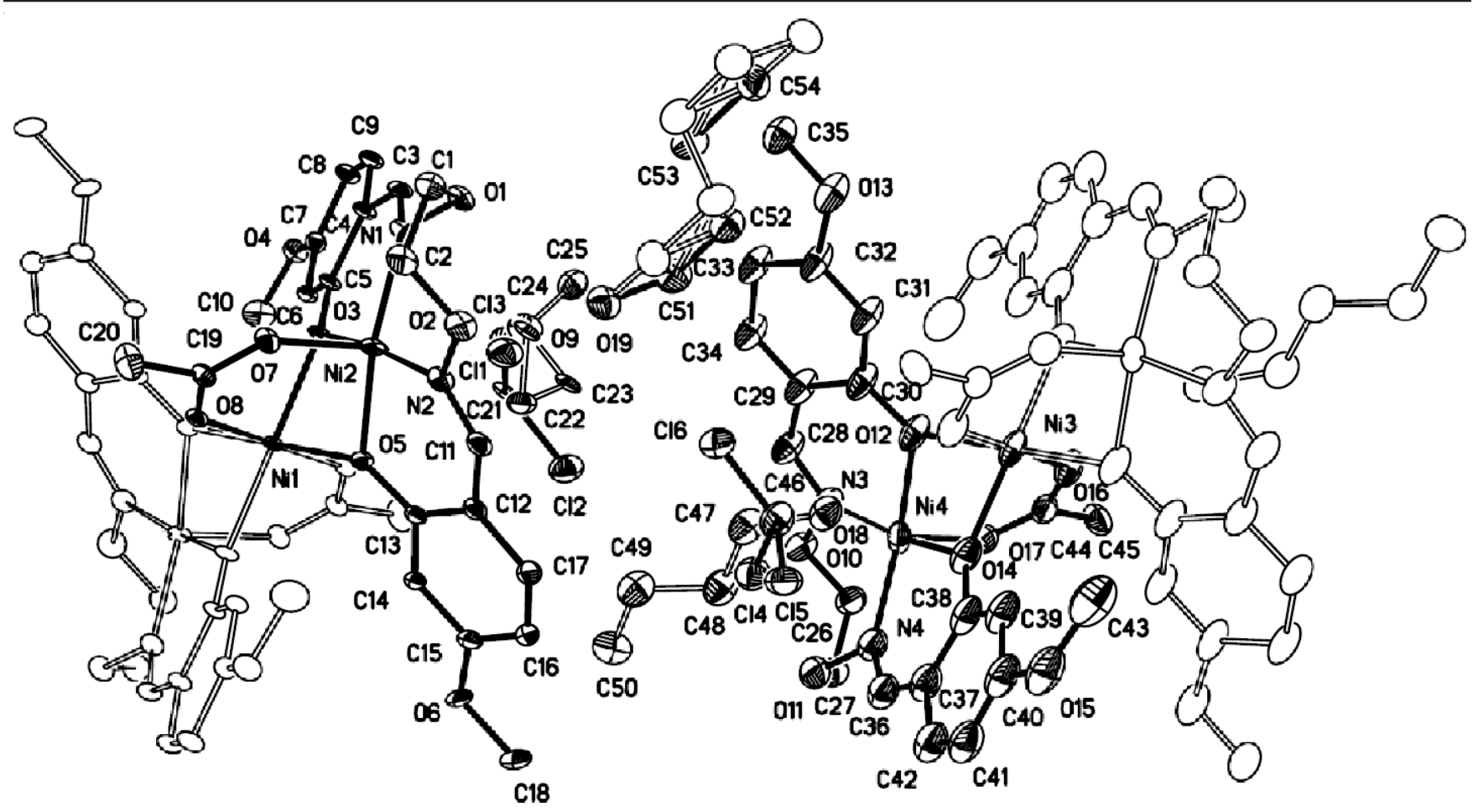

Fig. 1. Molecular structure of the Ni(II) complex

\section{ACKNOWLEDGEMENTS}

The authors thank The Young Scholars Science Foundation of Lanzhou Jiaotong University (2011007) and The Fundamental Research Funds for the Gansu Province Universities for financial support of this work.

\section{REFERENCES}

S. Akine, T. Taniguchi and T. Nabeshima, Chem. Lett., 30, 682 (2001). L. Xu, Y.P. Zhang and Y.X. Sun, Chin. J. Inorg. Chem., 23, 1999 (2007). W.K. Dong and Y.J. Ding, Cryst. Res. Technol., 43, 321 (2008).
4. S. Akine, W.K. Dong and T. Nabeshima, Inorg. Chem., 45, 4677 (2006).

5. W.K. Dong, J.G. Duan and G.L. Liu, Transition Met. Chem., 32, 702 (2007).

6. J. Reglinski, S. Morris and D.E. Stevenson, Polyhedron, 21, 2167 (2002).

7. W.K. Dong, Y.X. Sun, C.Y. Zhao, X.Y. Dong and L. Xu, Polyhedron, 29, 2087 (2010).

8. W.K. Dong, L. Li, C.F. Li, L. Xu and J.G. Duan, Spectrochim. Acta A, 71, 650 (2008)

9. G.M. Sheldrick, SHELXS97, Program for Crystal Structure Determination, University of Göttingen, Germany (1996).

10. G.M. Sheldrick, Acta Crystallogr. A, A64, 112 (2008).

11. W.K. Dong, J.G. Duan, L.Q. Chai, G.L. Liu and H.L. Wu, J. Coord. Chem., 61, 1306 (2008). 